\title{
Amino-acid uptake by mussels, Mytilus edulis, from natural sea water in a flow-through system
}

\author{
D. Siebers \& A. Winkler \\ Biologische Anstalt Helgoland (Zentrale); Notkestr. 31, D-2000 Hamburg 52, \\ Federal Republic of Germany
}

\begin{abstract}
Natural Wadden Sea water taken from the North Sea (island of Sylt) was pumped at rates of 150 and $300 \mathrm{I} \mathrm{h}^{-1}$ through a $4 \mathrm{l}$ plexiglass tube mounted on a wooden tripod on the beach. The tube was densely filled with numerous cleaned mussels, Mytilus edulis. HPLC analysis of sea water showed that total dissolved amino acids are patchily distributed, varying by $100 \%$ within 15 min, though proportions of individual amino acids were remarkably constant. Total amino-acid concentrations were $1528 \pm 669 \mathrm{nM}(\mathrm{N}=3)$ in October 1983 and $1198 \pm 597 \mathrm{nM}(\mathrm{N}=7)$ in July 1984. Samples taken at the entrance and the outlet of the experimental mussel bed revealed that the mussels had taken up 29 to $66 \%$ of the amino acids dissolved in sea water. Uptake was observed for all amino acids detected in the chromatograms. $78 \%$ of uptake resulted from the 5 most concentrated amino acids: serine, alanine, glycine/threonine, ornithine, aspartic acid. The nutritional profit obtained from uptake of dissolved amino acids amounted to $12 \%(\mathrm{~N}=5$, range $5-23 \%$, flow rate $\left.150 \mathrm{l} \mathrm{h}^{-1}\right)$ and to $24 \%\left(\mathrm{~N}=3\right.$, range $13-38 \%$, flow rate $\left.300 \mathrm{l} \mathrm{h}^{-1}\right)$ of metabolic rate. The present data suggest that amino-acid concentration predominantly determines the magnitude of the nutritional profit obtained from uptake, and to a smaller extent the flow rate. These findings are in contrast to results of previous studies on Asterias rubens, interacting in small-volume closed systems with the natural bacterial sea water flora (Siebers, 1982). In these experiments, bacteria, due to rapid uptake, outcompeted the sea stars in absorption of dissolved amino acids. The present results suggest that bivalve mussels, can, due to their large gill surface areas and the great amounts of water pumped through their mantle cavity, successfully compete with bacteria in uptake of dissolved organic matter. Mussels, therefore, suggestedly play an important role in cycling dissolved organic matter.
\end{abstract}

\section{INTRODUCTION}

All soft-bodied marine invertebrates so far investigated, have revealed the capability of absorption across their body surfaces of low molecular weight organic compounds dissolved in trace amounts in natural water bodies. It has been shown that the substances taken up were incorporated into tissues and processed via metabolic pathways (Jørgensen, 1976; Stewart, 1979; Stephens, 1981).

By virtue of the high rate of water flow through their mantle cavity and the large surface area of their gills, bivalve molluscs have been frequently used to study uptake of dissolved organic matter (DOM). Experimental approaches included employment of isolated gill tissue (Bamford \& Gingles, 1974; Bamford \& McCrea, 1975; Stewart \& Bamford, 1975, 1976; Wright et al., 1975; Bamford \& Campbell, 1976; Stewart, 1977, 1978, 1981; Wright \& Stephens, 1977; Gomme, 1982; Wright, 1982; Wright et al., 1984) 
and whole animals (Anderson \& Bedford, 1973; Péquinat, 1973; Crowe et al., 1977; Stewart, 1977. 1981; Manahan et al., 1982; Jørgensen, 1982, 1983; Wright, 1982; Manahan et al., 1983). Uptake of DOM in bivalve larvae has been studied by Fankboner \& De Burgh (1978), Manahan (1983a, b), Manahan \& Richardson (1983), and Manahan et al. (1983).

These experiments have shown that the gills of bivalves are primarily responsible for the removal of dissolved amino acids. The uptake is an active process, which proceeds selectively via specific carriers for sugars and amino acids against a concentration gradient of several orders of magnitude. The process is furthermore dependent on the external salinity and Na-concentration and is susceptible to the presence of metabolic inhibitors.

Several studies were concerned with removal of dissolved amino acids during a single passage of water through the mantle cavity by comparing amino-acid concentration in the inhalent and excurrent water (Wright \& Stephens, 1978; Manahan et al., 1982; Wright, 1982; Manahan et al., 1983). These studies showed that bivalves are capable of removing large fractions of amino acids during a single passage of water through the mantle cavity. Uptake proceeded at normal environmental concentrations of a few $\mu$ moles $1^{-1}$ and provided - on a calculation basis - a significant supplementary nutritional input of reduced carbon and amino nitrogen.

The effective $K_{t}$ of glycine uptake by intact mussels was between 2 and $5 \mu \mathrm{M}$, an order of magnitude lower than $\mathrm{K}_{\mathrm{t}}$ - values obtained from isolated gill tissues. Wright \& Stephens (1978) attributed this increased affinity in intact individuals of Mytilus californianus to an increase in the effective thickness of unstirred layers on the surface of isolated gills.

All these studies have in common that they were performed in closed systems with relatively small volumes of usually less than $500 \mathrm{ml}$ of mostly artificial sea water, to which, with one exception in the work by Manahan et al. (1982), individual amino acids were added by the experimentalist.

Our experiments with mussels, Mytilus edulis, were designed to work a step closer to in-situ conditions encountered in coastal waters. They were performed on the beach of List in the North of the island of Sylt (North Sea), using unprocessed sea water in an open system, which was directly pumped from the Wadden Sea through an experimental mussel bed. At the entrance and the exit of this mussel bed, sea water samples were taken and instantly analyzed for dissolved amino acids by HPLC. The data obtained were then used for calculations of potential nutritional benefits from amino acid uptake.

\section{MATERIALS AND METHODS}

\section{The experimental mussel bed}

Sea water from the Wadden Sea was pumped through a 41 plexiglass tube of $103 \mathrm{~cm}$ length and $7 \mathrm{~cm}$ inner diameter, which was mounted on a wooden tripod located close to the highwater line on the beach (Fig. 1). In order to secure continuous pumping during the tidal rhythm, the electric pump was positioned below low tide surface level. The plexiglass tube was densely filled with mussels, Mytilus edulis, which had been freshly collected in a near-by mussel area. The mussels had shell lengths of about $5 \mathrm{~cm}$., In 
October 1983 we used 184 specimens with a total fresh weight (including shells) of $2737 \mathrm{~g}$. In July 1984, we used 153 mussels with a total fresh weight of $2235 \mathrm{~g}$. Before insertion into the tube, the mussel shells were cleaned with a coarse brush. Sea water was pumped through the tube at flow rates of 150 and $3001 \mathrm{~h}^{-1}$. The mussel shells opened within a few minutes, and active pumping was observed. Sea water samples were then taken simultaneously at the entrance and the outlet of the mussel tube in order to determine the potential differences in concentrations of dissolved amino acids resulting from uptake by the mussels. Sea water temperatures were $14^{\circ} \mathrm{C}$ in October 1983 and $16^{\circ} \mathrm{C}$ in July 1984.

\section{HPLC analysis of dissolved amino acids}

Sea water samples (approx. $5 \mathrm{ml}$ ) taken at the entrance and the outlet of the plexiglass tube were filtered through a $0.22 \mu \mathrm{m}$ Millipore filter and stored deep-frozen $\left(-25^{\circ} \mathrm{C}\right)$ for no longer than $1 \mathrm{~h}$ prior to analysis.

Fluorescent derivatives of sea water samples were prepared according to Liebezeit \& Dawson (1981) by addition of $0.1 \mathrm{ml} 0.4 \mathrm{M} \mathrm{K}$-borate buffer, $\mathrm{pH} \mathrm{11.6}$, and $0.01 \mathrm{ml}$ OPA reagent ( $50 \mathrm{mg}$ o-phthaldialdehyde $+0.5 \mathrm{ml}$ methanol $+0.025 \mathrm{ml}$ mercaptoethanol) to $1 \mathrm{ml}$ of sea water. The reaction was terminated after $2 \mathrm{~min}$ by addition of $0.1 \mathrm{ml} 1 \mathrm{M}$ $\mathrm{NaH}_{2} \mathrm{PO}_{4}$ (Jones et al., 1981). Thereafter, $0.2 \mathrm{ml}$ of derivatized solution were injected onto the column.

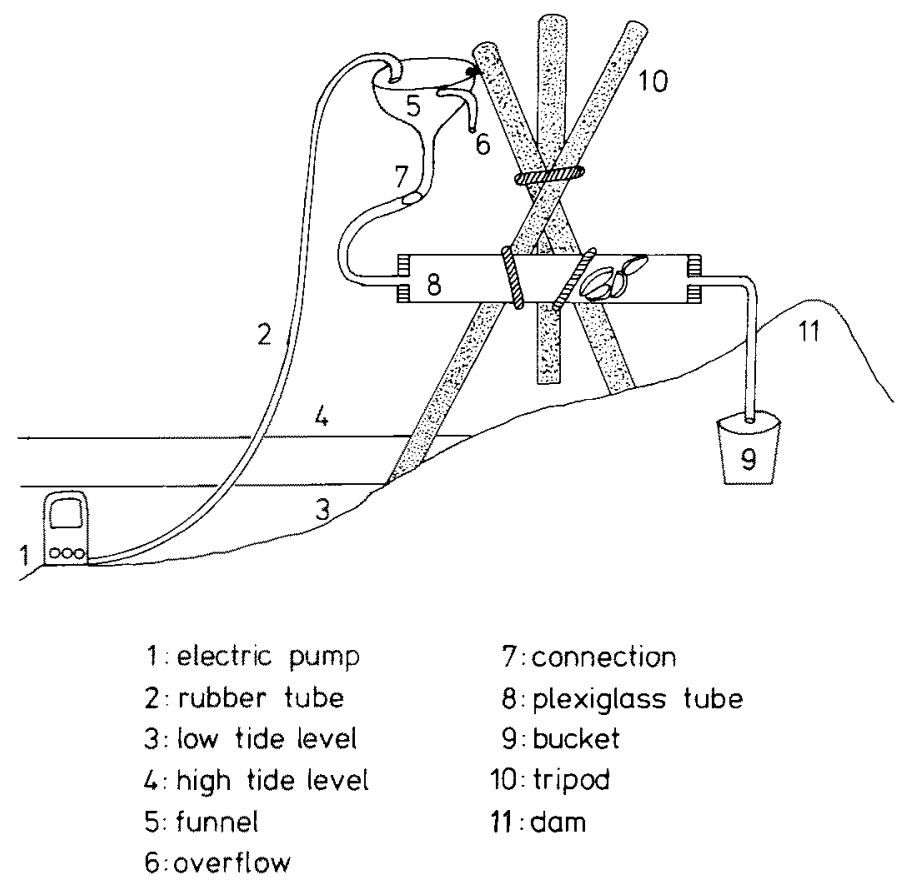

Fig. 1. Mytilus edulis. Schematic representation of the experimental mussel bed enclosed in a flowthrough system. The tube was filled with 184 mussels in October 1983 and with 153 mussels in July 1984. The flow rates of sea water were 150 and $300 \mathrm{I} \mathrm{h}^{-1}$ 
The HPLC system (LDC, Milton Roy) consisted of 2 pumps, controlled by a gradient former, a $0.2 \mathrm{ml}$ loop inserted in a Rheodyne injection port, and the column $(25 \times 0.4 \mathrm{~cm})$, filled with RP 18 phase (Spherisorb ODS $5 \mu$ ). The column was protected by a precolumn $(2 \times 0.4 \mathrm{~cm})$ filled with the original RP 18 phase. Individual OPA derivatives of amino acids eluting from the column were detected by a fluorimeter, recorded and integrated on a Shimadzu C-R1B recorder/integrator.

Separation of the derivative mixture was performed according to Lindroth \& Mopper (1979) by a linear elution gradient of $\mathrm{A} 0.05 \mathrm{M} \mathrm{Na} \mathrm{HPO}_{4} / \mathrm{NaH}_{2} \mathrm{PO}_{4}, \mathrm{pH} 7.2$ and $\mathrm{B}$ methanol, starting with $15 \% \mathrm{~B}$ and, after a 5 min delay, changing to $60 \% \mathrm{~B}$ within 45 min. The flow was $1.2 \mathrm{ml} \mathrm{min}^{-1}$, the resulting pressure was 3000 PSI. Quantification was obtained by comparison of peak areas with those of a standard amino-acid mixture. Replicate HPLC analyses of individual samples showed small variations of usually less than $3 \%$ in single components and total amino acid levels.

\section{RESULTS}

\section{HPLC spectra}

HPLC spectra obtained from samples taken at the entrance and the outlet of the plexiglass tube containing the experimental mussel bed are shown in Figure 2. Compared with the spectrum of the standard amino-acid mixture (Fig. 2A), sea water (Fig. 2B) contained practically all amino acids normally found in protein hydrolysates, however, in highly differing concentrations. Baseline increase at the end of the chromatogram may result from fluorescent materials in sea water eluting in the neighbourhood of the last 2 amino acids, ornithine and lysine. Sea water compositions of amino acids containing large proportions of aspartic acid, serine, glycine, alanine and basic compounds such as ornithine and lysine are well known from literature (Dawson \& Pritchard, 1978).

Variations in total concentrations of dissolved amino acids detected in samples taken at the entrance of the mussel tube were considerably high, amounting to $1528 \pm$ $669 \mathrm{nM}\left(\mathrm{n}=3\right.$, October 1984) and $1198^{ \pm} 597 \mathrm{nM}(\mathrm{n}=7$, July 1984), though relative proportions of individual components were remarkably constant. In 1983, samples were taken at $6-8 \mathrm{~h}$ intervals. In 1984, we followed amino-acid levels in sea water from low tide to high tide, when coastal water streamed eastward to the Wadden Sea through the gap between the islands Sylt and Romø. The following data give an impression on the velocity of changes of total amino acids in coastal water. We started at low tide (7.30 a. m.) and measured in duplicate analyses total amino-acid concentrations of $1006 \mathrm{nM}$ at 9.25 a. m., $2419 \mathrm{nM}$ at $9.45,954 \mathrm{nM}$ at $10.35,1257 \mathrm{nM}$ at $10.50,651 \mathrm{nM}$ at $11.05,1367 \mathrm{nM}$ at $12.12 \mathrm{p} . \mathrm{m}$. , and $730 \mathrm{nM}$ at 12.20 . These data imply that the patchy distribution of amino acids in coastal water is not correlated to the tidal cycle. The concentrations of amino acids found in our experiments 1983 and 1984 correspond closely to published values for total amino-acid concentrations measured in coastal waters, amounting to 500 to $2000 \mathrm{nM}$ (North, 1975; Jørgensen, 1976a). 
A $\quad$-AIE
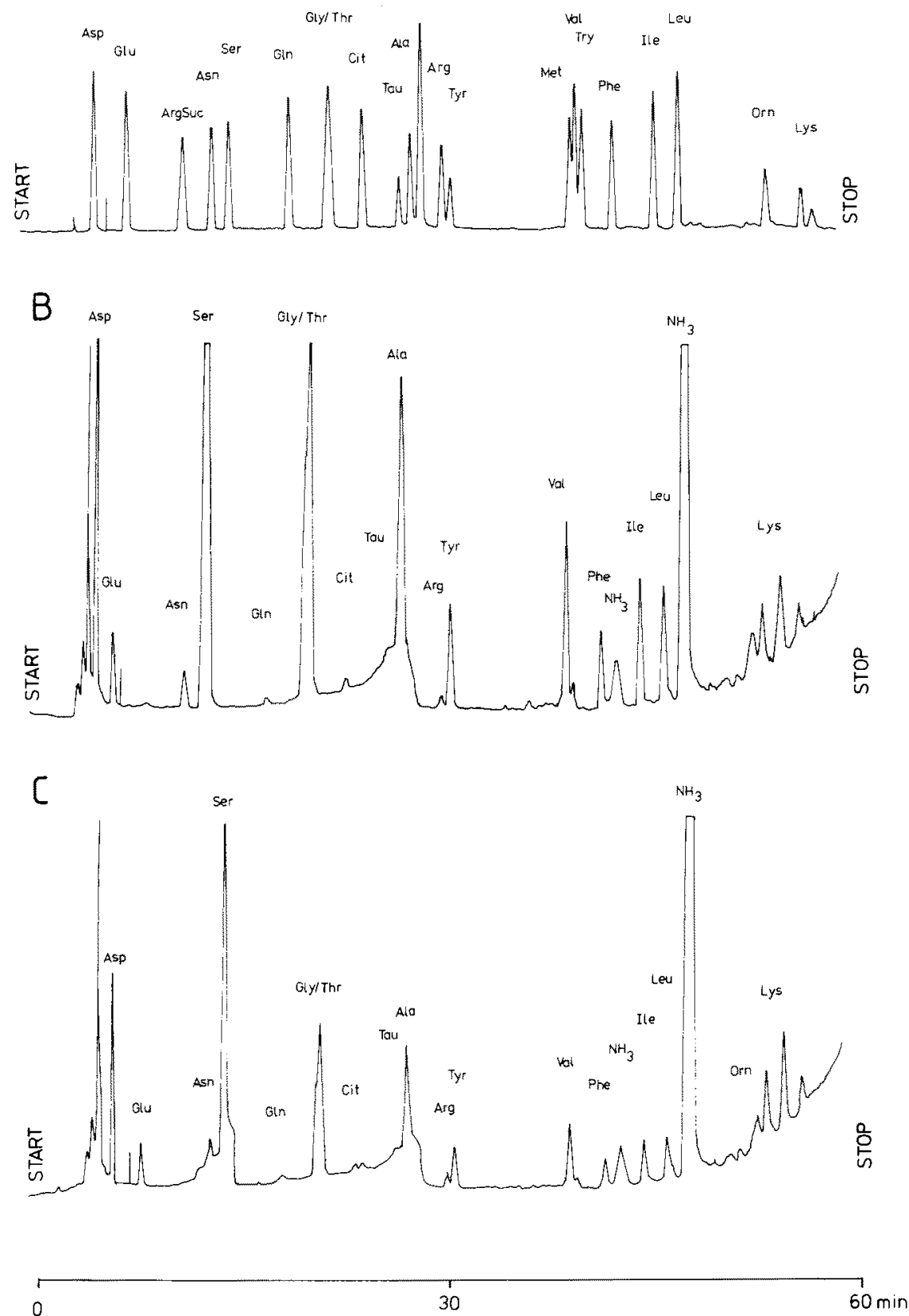

Fig. 2. Mytilus edulis. HPLC spectra of amino acids in sea water samples taken at the entrance (B) and the outlet $(C)$ of the experimental mussel bed in comparison to a standard amino acid mixture (A) (8 pmoles per component) 


\section{Amino-acid uptake by Mytilus edulis}

Visual comparison of chromatograms obtained from samples taken at the entrance (Fig. 2B) with samples taken at the outlet (Fig. 2C) of the experimental mussel bed indicates that all amino acids were reduced at the outlet. Quantitative analysis of another run, also performed with a sea water flow of $150 \mathrm{l} \mathrm{h}^{-1}$, confirmed that all aminoacids, without exception, were reduced at the outlet of the plexiglass tube (Table 1). $78 \%$ of the total difference resulted from the 5 most concentrated amino-acids: serine, alanine, glycine/threonine, ornithine, and aspartic acid. But even the less concentrated amino-acids: glutamic acid, asparagine, and phenylalanine were significantly reduced to levels below $10 \mathrm{nM}$. Total amino-acids were reduced from $765 \mathrm{nM}$ by $354 \mathrm{nM}(46 \%$ of total).

For controls, empty mussel shells collected in the Wadden Sea at low tide were used. Mussels with their two shells still connected to each other were cleaned as the experimentals and kept closed under water with an elastic thread. When these controls were inserted into the tube, we could not detect a decrease in dissolved amino acids at the outlet compared to entrance levels. On the contrary, we found a slight increase of 5-10\% $(n=4)$. This increase may be due to analytical variations, short-term concentration changes and potentially also to microorganisms degrading the proteinous matrix of the outer shell surface. This degradation may occur at much reduced rates in intact live mussels.

\section{Estimation of nutritional benefits}

The total fresh weight of mussels consisted of $37 \%$ sea water contained in the mantle cavity, $37 \%$ empty shells, and $26 \%$ total wet mussel tissue; that is $712 \mathrm{~g}$ wet

Table 1. Mytilus edulis. Amino acid concentrations in sea water samples taken at the entrance and the outlet of the experimental mussel bed $\left(\mathrm{N}=184,1983,14^{\circ} \mathrm{C}\right.$, flow rate $\left.=1501 \mathrm{~h}^{-1}\right)$

\begin{tabular}{|lrrr|}
\hline Amino acid & \multicolumn{2}{c}{ Concentration (nM) at } & Difference \\
& Entrance & Outlet & $(\%)$ \\
\hline Asp & 41 & 22 & 46 \\
Glu & 16 & 10 & 38 \\
Asn & 8 & 3 & 63 \\
Ser & 147 & 60 & 59 \\
Glu & 5 & 3 & 40 \\
Gly/Thr & 113 & 51 & 55 \\
Tau & 14 & 6 & 57 \\
Ala & 120 & 56 & 53 \\
Arg & 10 & 9 & 10 \\
Tyr & 15 & 7 & 53 \\
Val & 23 & 9 & 61 \\
Phe & 11 & 5 & 55 \\
Ile & 15 & 6 & 60 \\
Leu & 21 & 13 & 38 \\
Orn & 93 & 48 & 48 \\
Lys & 113 & 103 & 9 \\
Total & 765 & 411 & 46 \\
\hline
\end{tabular}


tissue in 1983 and $581 \mathrm{~g}$ in 1984. Considering the dry flesh weight of Mytilus edulis obtained from a salinity of $30 \%$ to be $22.4 \pm 1.4 \mathrm{~g}(\mathrm{n}=12)$ per $100 \mathrm{~g}$ fresh weight (Keuker, pers. comm.), the mussel bed contained $159 \mathrm{~g}$ dry tissue weight in 1983 and $130 \mathrm{~g}$ in 1984. Mussels of $0.85 \mathrm{~g}$ dry weight (per individual) used in our experiments consume oxygen at $15^{\circ} \mathrm{C}$ at rates of approx. $0.5 \mathrm{ml} \mathrm{O}_{2} \mathrm{~g}_{\text {dry weight }}^{-1} \mathrm{~h}^{-1}$ (Bayne, 1975; Jørgensen, 1976b; Hamburger et al., 1983).

Uptake of total amino acids in experiment 1 (see Tables 1, 2) was $354 \mathrm{nM}$. At a flow rate of $1501 \mathrm{~h}^{-1}$, uptake amounted to $53.1 \mu$ moles $\mathrm{h}^{-1}$ in the mussel bed or, setting the mean molecular weight of the amino acid mixture taken up as $100 \mathrm{~g} \mathrm{~mole}^{-1}, 5.31 \mathrm{mg}$. Taking $1 \mathrm{mg}$ of mixed amino acids as equivalent to $1 \mathrm{ml} \mathrm{O}_{2}$ for complete oxidation, the amino acids taken up are equivalent to $5.31 \mathrm{ml} \mathrm{O}_{2}$. This figure, when compared to total $\mathrm{O}_{2}$ uptake of $79.5 \mathrm{ml} \mathrm{h}^{-1}$, amounts to $7 \%$ of metabolic rate (see Table 2).

The nutritional profit obtained from uptake of dissolved amino acids amounted to $12 \%$ $(\mathrm{N}=5$, range $5-23 \%)$ of the metabolic rate at a flow rate of $1501 \mathrm{~h}^{-1}$ and to $24 \%(\mathrm{~N}=3$, range $13-38 \%$ ) of metabolic rate at a flow rate of $300 \mathrm{l} \mathrm{h}^{-1}$ (Table 2 ). It is obvious that the given amino-acid concentration predominantly determines the magnitude of the nutritional profit obtained from uptake, and to a smaller extent the flow rate.

\section{DISCUSSION}

Since the pioneer work by Lindroth \& Mopper (1979), it is possible to separate amino acids as their fluorescent precolumn o-phthaldialdehyde derivatives by means of reversed phase HPLC. This procedure is so sensitive that the detection limit lies in the femtomole range and amino acids naturally occurring in coastal waters at total concentrations between 0.5 and $2 \mu \mathrm{M}$ can successfully be analyzed without prior clean-up or concentration steps. Our data confirm previous reports on amino-acid concentrations in

Table 2. Mytilus edulis. Nutritional profit obtained from uptake of dissolved amino acids from natural sea water in an experimental flow-through mussel bed. Water temperatures: $14^{\circ} \mathrm{C}$ (in 1983) and $16^{\circ} \mathrm{C}$ (in 1984)

\begin{tabular}{|c|c|c|c|c|c|}
\hline \multirow[t]{2}{*}{$\begin{array}{l}\text { Experiment } \\
\text { No. }\end{array}$} & \multicolumn{2}{|c|}{$\begin{array}{l}\text { Amino-acid concentrations } \\
\text { (nM) at }\end{array}$} & \multirow[t]{2}{*}{$\begin{array}{l}\text { Flow rate } \\
\qquad\left(1 \mathrm{~h}^{-1}\right)\end{array}$} & \multirow[t]{2}{*}{$\begin{array}{l}\text { Uptake of amino } \\
\text { acids }\left(\mathrm{mg} \mathrm{h}^{-1}\right)\end{array}$} & \multirow[t]{2}{*}{$\begin{array}{l}\% \text { Metabolic } \\
\text { rate }\end{array}$} \\
\hline & Entrance & Outlet & & & \\
\hline 1 (1983) & 765 & 411 & 150 & 5.3 & 7 \\
\hline 2 (1983) & 1805 & 900 & 150 & 13.6 & 17 \\
\hline 3 (1984) & 1007 & 592 & 150 & 6.2 & 10 \\
\hline $4(1984)$ & 2419 & 1423 & 150 & 14.9 & 23 \\
\hline \multirow[t]{3}{*}{5 (1984) } & 954 & 735 & 150 & 3.3 & 5 \\
\hline & & & & Mean & $\sqrt{12}$ \\
\hline & & & & Range & e $5-23$ \\
\hline $6(1983)$ & 2015 & 1435 & 300 & 17.4 & 22 \\
\hline 7 (1984) & 1257 & 432 & 300 & 24.8 & 38 \\
\hline \multirow[t]{3}{*}{$8(1984)$} & 651 & 361 & 300 & 8.7 & 13 \\
\hline & & & & Mean & 24 \\
\hline & & & & Range & e $13-38$ \\
\hline
\end{tabular}


coastal waters, ranging between 0.5 and $2.0 \mu \mathrm{M}$ (North, 1975; Jørgensen, 1976a). In addition, we could show that total amino-acid levels vary greatly within short time periods, although individual proportions were remarkably constant. The patchy distribution of total dissolved amino acids is obviously not due to the momentary state of the tidal cycle.

Our uptake experiments aimed to simulate in-situ conditions as closely as possible by use of mussels in a densely crowded mussel bed enclosed in an open flow-through system. Employment of natural, unprocessed sea water directly pumped through the mussel bed guaranteed that there was no manipulation of the medium.

These experiments showed that Mytilus edulis can deplete the sea water of individual amino acids down to concentrations below $10 \mathrm{nM}$ and total amino acids to levels about $0.4 \mathrm{nM}$. The mussels took up between 30 and $50 \%$ of the amino acids dissolved in coastal water and obtained nutritional benefits from the uptake equivalent to 5 to $38 \%$ of metabolic rate. These findings agree well with the results obtained by the authors measuring amino acid uptake during a single passage of water through the mantle cavity of bivalves (for literature see "Introduction"). Our results suggest that the magnitude of nutritional profit depends on the momentary amino-acid concentration and to a minor degree on the flow rate of water through the tube, which may have a natural correlate in the movement of sea water across mussel beds.

Regarding the nutrition of bivalves, our results confirm previous publications (for literature see "Introduction") that besides retention of particles by the gills uptake of dissolved organic matter provides a significant supplementary nutritional input. This source is continuously available, though varying with DOM concentrations and temperature-depending metabolic rates.

The flow rates of sea water through the mussel tube can be compared with the filtration rates in Mytilus edulis. Filtration rates follow the general allometric equation $\mathrm{F}$ $=\mathrm{a} \cdot \mathrm{W}^{\mathrm{b}}$ where $\mathrm{F}=$ filtration rate $\left(1 \mathrm{~h}^{-1}\right), \mathrm{W}=$ dry tissue weight $(\mathrm{g})$, $\mathrm{a}$ and $\mathrm{b}=$ constants, which depend on species, developmental stage and experimental variables. By using the data for $\mathbf{a}$ and $\mathrm{b}$ obtained at temperatures close to $15^{\circ} \mathrm{C}$ by several authors, we calculated the filtration rates of individuals of Mytilus edulis of $0.85 \mathrm{~g}$ dry weight used in our experiments. Multiplication with the number of individuals enclosed in the experimental mussel bed (184 in 1983) resulted in an estimate of the filtration rate of total mussels in the experiments, amounting to $2211 \mathrm{~h}^{-1}$ (data from Willemsen, 1952), $3271 \mathrm{~h}^{-1}$ (data from Theede, 1963), $3981 \mathrm{~h}^{-1}$ (data from Winter, 1973) and $14131 \mathrm{~h}^{-1}$ (data from Riisgård \& Møhlenberg, 1979). Comparison of filtration rates with the flow rates of sea water through the mussel tube shows that with one exception (data from Riisgård \& Møhlenberg, 1979) the filtration rates calculated are in the order of the experimental flow rates employed (150 and $3001 \mathrm{~h}^{-1}$ ).

Since under natural conditions the degree of water exchange in the vicinity of a mussel bed is unknown, but certainly varies greatly, it must be assumed that sea water may pass the mantle cavity several times. This is certainly also the case in our experiments and provides an explanation for the higher nutritional profits obtained at the higher flow rate of $3001 \mathrm{~h}^{-1}$.

The findings that mussels can effectively absorb DOM from the low concentrations encountered in their natural environment and that these uptake processes provide significant nutritional profit are in contrast to previous results (Siebers, 1982) obtained 
from experiments on interactions between the sea star, Asterias rubens, and the natural bacterial water flora. In these experiments, performed in closed systems, bacteria outcompeted the sea stars in absorption of dissolved amino acids, due to rapid uptake. The deduction that bacteria instantly respond to suitable levels of DOM with effective uptake, thus keeping local concentrations at such low levels that no nutritionally significant uptake can take place in invertebrates can - on the basis of our present results with Mytilus edulis - no longer be regarded as valid. Obviously, bacterial uptake and growth does not result in concentrations of DOM too low to be used by Mytilus. In this context, mechanisms of antibacterial activity in sea water (Moebus, 1972 a-d) may play a role. It seems that at least a few metazoans, among them several bivalve mussels, can, due to their large gill surface areas and the great amounts of water pumped through their mantle cavity, successfully compete with bacteria in uptake of DOM.

Our results, that the mussel bed enclosed in an open flow-through plexiglass tube depleted the sea water by 30 to $50 \%$ of originally dissolved amino acids, are also in contrast to the statement by Sepers (1977) who argued that in natural waters the uptake of dissolved organic compounds is primarily a bacterial process. Our present findings suggest that mussel beds in shallow coastal waters exposed to tidal movements of large sea water masses play a significant role in recycling of DOM.

Acknowledgements. This research is part of the program "Stoffwechsel unter Extrembedingungen" of the Deutsche Forschungsgemeinschaft, the grant for which (Sie 295/1-1) is gratefully accepted.

\section{LITERATURE CITED}

Anderson, J. W. \& Bedford, W. B., 1973. The physiological response of the estuarine clam, Rangia cuneata (Gray), to salinity. II. Uptake of glycine. - Biol. Bull. mar. biol. Lab., Woods Hole 144, 229-242.

Bamford, D. R. \& Gingles, R., 1974. Absorption of sugars in the gill of the Japanese oyster, Crassostrea gigas. - Comp. Biochem. Physiol. 49 A, 637-646.

Bamford, D. R. \& McCrea, R., 1975. Active absorption of neutral and basic amino acids by the gill of the common cockle, Cerastoderma edule. - Comp. Biochem. Physiol. 50 A, 811-817.

Bamford, D. R. \& Campbell, E., 1976. The effect of environmental factors on the absorption of $\alpha$ phenylalanine by the gill of Mytilus edulis. - Comp. Biochem. Physiol. 53 A, 295-299.

Bayne, B. L., 1975. Aspects of physiological condition in Mytilus edulis L., with special reference to the effects of oxygen tension and salinity. In: 9th European Marine Biology Symposium. Ed. by $H$. Barnes. Aberdeen Press, Aberdeen, 213-238.

Crowe, J. H., Dickson, K. A., Colon, R. D. \& Farley, K. K., 1977. Uptake of amino acids by the mussel, Modiolus demissus. - J. exp. Zool. 202, 323-332.

Dawson, R. \& Pritchard, R. G., 1978. The determination of $\alpha$-amino acids in seawater using a fluorimetric analyser. - Mar. Chem. 6, 27-40.

Fankboner, P. V. \& De Burgh, M. E., 1978. Comparative rates of dissolved organic carbon accumulation by juveniles and pediveligers of the Japanese oyster Crassostrea gigas Thunberg. Aquaculture 13, 205-212.

Gomme, J., 1982. Laminar water flow, amino acid absorption, and amino acid recycling in the mussel gill. - Am. Zool. 22, 898 (Abstr.).

Hamburger, K., Møhlenberg, I., Randløv, A. \& Riisgård, H. U., 1983. Size, oxygen consumption and growth in the mussel Mytilus edulis. - Mar. Biol. 75, 303-306.

Jørgensen, C. B., 1976a. August Pütter, August Krogh, and modern ideas on the use of dissolved organic matter in aquatic environments. - Biol. Rev. 51, 291-328.

Jørgensen, C. B., 1976b. Growth efficiencies and factors controlling size in some mytilid bivalves, especially Mytilus edulis L.: Review and interpretation. - Ophelia 15, 175-192. 
Jørgensen, C. B., 1982. Uptake of dissolved amino acids from natural sea water in the mussel Mytilus edulis. - Ophelia 21, 215-221.

Jørgensen, C. B., 1983. Patterns of uptake of dissolved amino acids in mussels (Mytilus edulis). Mar. Biol. 73, 177-182.

Jones, B. N., Pääbo, S. \& Stein, S., 1981. Amino acid analysis and enzymatic sequence determination of peptides by an improved o-phthaldialdehyde precolumn labeling procedure. - J. Liquid Chromatogr. 4, 565-586.

Liebezeit, G. \& Dawson, R., 1981. Isoindole derivatives of amino acids for HPLC separations. Effect of reaction $\mathrm{pH}$ and time on fluorescence yield. - J. High Resolut. Chromatogr. Chromatogr. Communs 4, 354-356.

Lindroth, P. \& Mopper, K., 1979. High performance liquid chromatographic determination of subpicomole amounts of amino acids by precolumn fluorescence derivatization with o-phthaldialdehyde. - Analyt. Chem. 51, 1667-1674.

Manahan, D. T., Wright, S. H., Stephens, G. C. \& Rice, M. A., 1982. Transport of dissolved amino acids by the mussel, Mytilus edulis: Demonstration of net uptake from natural sea water. Science, N. Y. 215, 1253-1255.

Manahan, D. T., 1983a. The uptake and metabolism of dissolved amino acids by bivalve larvae.Biol, Bull. mar. biol. Lab., Woods Hole 164, 236-250.

Manahan, D. T., 1983b. The uptake of dissolved glycine following fertilization of oyster eggs, Crassostrea gigas (Thunberg). - J. exp. mar. Biol. Ecol. 68, 53-58.

Manahan, D. T. \& Richardson, K., 1983. Competition studies on the uptake of dissolved organic nutrients by bivalve larvae (Mytilus edulis) and marine bacteria. - Mar. Biol. 75, 241-247.

Manahan, D. T., Davis, J. P. \& Stephens, G. C., 1983. Bacteria free sea urchin larvae: Selective uptake of neutral amino acids from sea water. - Science, N. Y. 220, 204-206.

Manahan, D. T., Wright, S. H. \& Stephens, G. C., 1983. Simultaneous determination of net uptake of 16 amino acids by a marine bivalve. - Am. J. Physiol. 244, 832-838.

Moebus, K., 1972a. Seasonal changes in antibacterial activity of North Sea water, - Mar. Biol. 13, $1-13$.

Moebus, K., 1972b. The influence of storage on antibacterial activity of sea water, - Mar. Biol. 13, 346-351.

Moebus, K., 1972c. Bacterial properties of natural and synthetic sea water as influenced by addition of low amounts of organic matter, - Mar. Biol. 15, 81-88.

Moebus, K., 1972d. Studies on the influences of plankton on antibacterial activity of sea water. Helgoländer wiss. Meeresunters. 23, 127-140.

North, B. B., 1975. Primary amines in California coastal waters: utilization by phytoplankton. Limnol. Oceanogr. 20, 20-27.

Péquinat, E., 1973. A kinetic and autoradiographic study of the direct assimilation of amino acids and glucose by organs of the mussel, Mytilus edulis. - Mar. Biol. 19, 227-244.

Riisgård, H. U. \& Møhlenberg, F., 1979. An improved automatic recording apparatus for determining the filtration rate of Mytilus edulis as a function of size and algal concentration. - Mar. Biol. 52, 61-67.

Sepers, A. B. J., 1977. The utilization of dissolved organic compounds in aquatic environments. Hydrobiologia 52, 39-54.

Siebers, D., 1982. Bacterial-invertebrate interactions in uptake of dissolved organic matter. - Am. Zool. 22, 223-233.

Stephens, G. C., 1981. The trophic significance of dissolved organic material. In: Analysis of marine ecosystems. Ed. by A. L. Longhurst. Acad. Press, New York, 271-291.

Stewart, M. G. \& Bamford, D. R., 1975. Kinetics of alanine uptake by the gills of the soft-shelled clam Mya arenaria. - Comp. Biochem. Physiol. 52 A, 67-74.

Stewart, M. G. \& Bamford, D. R., 1976. The effect of environmental factors on the absorption of amino acids by isolated gill tissue of the bivalve, Mya arenaria (L.). - J. exp. mar. Biol. Ecol. 24, 205-212.

Stewart, M. G., 1977. The uptake and utilization of dissolved amino acids by the bivalve Mya arenaria (L.). In: Physiology and behaviour of marine organisms. Ed. by D. S. McLusky \& A.J. Berry. Pergamon Press, Oxford, 165-176. 
Stewart, M. G., 1978. Kinetics of neutral amino acid transport by isolated gill tissue of the bivalve Mya arenaria (L.). - J. exp. mar. Biol. Ecol. 32, 39-52.

Stewart, M. G., 1979. Absorption of dissolved organic nutrients by marine invertebrates. Oceanogr. mar. Biol. 17, 163-192.

Stewart, M. G., 1981. Kinetics of dipeptide uptake by the mussel Mytilus edulis. - Comp. Biochem. Physiol. 69 A, 311-315.

Theede, H., 1963. Experimentelle Untersuchungen über die Filtrierleistung der Miesmuschel, Mytilus edulis L. - Kieler Meeresforsch. 19, $20-41$.

Willemsen, J., 1952. Quantities of water pumped by mussels (Mytilus edulis) and cockles (Cardium edule). - Archs néerl. Zool. 10, 152-160.

Winter, J, E., 1973. The filtration rate of Mytilus edulis and its dependence on algal concentration, measured by a continuous automatic recording apparatus. - Mar. Biol, 22, 317-328.

Wright, S. H., Johnson, T. L. \& Crowe, J. H., 1975. Transport of amino acids by isolated gills of the mussel, Mytilus californianus. - J. exp. Biol. 62, 313-325.

Wright, S. H. \& Stephens, G. C., 1977. Characteristics of influx and net flux of amino acids in Mytilus californianus. - Biol. Bull. mar. biol. Lab., Woods Hole 152, 295-310.

Wright, S. H. \& Stephens, G. C., 1978. Removal of amino acid during a single passage of water across the gill of marine mussel. - J. exp. Zool. 205, 337-352.

Wright, S. H., 1982. A nutritional role for amino acid transport in filter-feeding marine invertebrates. - Am. Zool. 22, 621-634.

Wright, S. H., Southwell, K. M. \& Stephens, G. C., 1984. Autoradiographic analysis of amino-acid uptake by the gill of Mytilus. - J. comp. Physiol. 154 B, 249-256. 